\title{
Angina do peito
}

\author{
O professor Ascendino dos Reis, que falle- \\ ceu em consequencia de um accesso de angina do \\ peito, defendeu these em Medicina sobre o "Diag- \\ nostico Differencial das Molestias do Coração". \\ encontrando-se entre as paginas do seu trabalho, \\ escripto em 1874, o trecho que a seguir transcre- \\ vemos, a respeito precisamente da angina do peito.
}

"Conhecida sob os nomes de "sternalgia, sterno-dynia, sternocardia, apnéa-cardica, nevralgia cardiaca, syncope anginosa” esta molestia é caracterizada essencialmente por dôres, que se manifestam por accessos, que parecem partir da ultima porção do sterno e do lado esquerdo do torax, e estender-se dahi profundamente para a columna vertebral.

A natureza desta molestia é indicada pelo nome que lhe deu Romberg, "hyperesthesia do plexo cardiaco", e comprovado pela forma dos accessos, separados por intervallos livres, a natureza e caracter das dôres, a sua irrradiação frequente para outras regióes, a integridade muito frequente das funcções respiratorias e circulatorias, e a coexistencia contante de outras nevralgias.

Distinguem-se duas formas de angina-pectoris: a "forma dynamica, essencial, idiopathica ou funccional" e a "forma organica" A primeira é propria dos individuos moços; a segunda, particular á edade avançada, é mais frequente do que a primeira, preferindo para a sua manifestação o sexo masculino ao feminino.

A forma dynamica é uma simples hyperesthesia, uma nevralgia primitiva do plexo cardiaco, sem alteração somatica. A forma organica tem relações estreitissimas com as degenerações, e com obliteração das arterias coronarias.

\section{ELEMENTOS PARA O DIAGNOSTICO.}

Qualquer que seja a sua causa determinante e a sua forma, as dôres sub-sternaes da angina que por sua séde e extensão correspondem aos plexos cardiacos, são acompanhadas daquellas sensações particulares, excessivamente penosas, que caracterisam as nevralgias do systema do grande sympathico. 
Uma oppressão e angustia inexprimiveis, uma constricção das mais angustiosas no epigastrio, uma dôr pungente na região do coração, uma suffocação imminente, uma immobilidade absoluta estando o doente sentado ou de pé, uma pallidez assustadora, tal é o quadro pelo qual se desenha a angina-pectoris. Parece, como diz Friedreich, que a vida é atacada em suas raizes mais profundas. O doente sente em si, na expressão de um notavel autor, como que a pausa universal das operações da natureza, e, aterrado, espera o termo desse ataque, que lhe ameaça a vida.

Comquanto exista a sensação subjectiva de dyspnéa, a respiração é livre e profunda, e não se accelera, se a angina é protopathica ou essencial.

Sendo a angina secundaria, nota-se difficuldades na respiração, mas dependentes da molestia primitiva.

O que é notavel, é que, com a regularidade da respiração, os batimentos cardiacos são fracos, ás vezes imperceptiveis, sempre desiguaes e intermittentes, e essas anomalias são reflectidas pelo pulso.

Terminado o accesso desapparecem todos estes phenomenos.

Se o caracter da dôr é sempre constrictivo e angustiante, a sua séde pode variar. Assim, ella pode occupar a metade direita da região precordial; seguir uma linha transversal que reuna os mamillos, ou atravessar de diante para traz o lado esquerdo do peito.

Os phenomenos dolorosos não se limitam á região precordial: irradiam-se, ora para o pescoço, para o mento e para a maxilla inferior, seguindo os ramos superficiaes do plexo cervical; ora para as inserções do musculo peitoral no humerus, donde se extendem aos cotovelos, ás vezes até o lado interno do antebraço e do punho, podendo chegar até os dedos, seguindo assim o trajecto dos nervos thoraxicos anteriores e dos ramos do cubital. Essas irradiações cervicobrachiaes são caracteristicas da molestia de que nos occupamos. Mas a dôr pode ainda, por execpção, irradiar-se para o epigastrio, o testiculo e até as coxas, como obbservou Friedreich uma vez.

'As vezes ha hyperesthesia cutanea na região thoraxica anterior; outras vezes ha dysphagia, por constricção do pharynge; pode haver nauseas e vomitos, pela invasão dos ramos gastricos do plexo, e soluços pela extensão ao nervo phrenico. A pressão, os movimentos respiratorios e os do braço não augmentam a dôr da angina. O accesso termina subitamente como começou e é caracterisado pela cessação da dôr. Então alguns phenomenos notaveis podem ser observados: eructações gazozas, vomiturações, em alguns casos necessidade irresistivel de urinar, inchação notavel do testiculo, apparição de uma nevralgia ilio-scrotal. Terminado o accesso só resta ao doente uma fadiga e alguma tristeza e anciedade, pelo temor de novo ataque.

A duração dos accessos é variavel entre alguns minutos ou instantes e algumas horas. O intervallo entre elles é tambem de variavel 
duração, ora separados por mezes e annos, os accessos reproduzem-se ás vezes todos os dias, ou de hora em hora. Em geral, quanto mais se repetem os ataques, menor vai sendo o intervallo entre elles. Não sendo organica a angina, o doente não apresenta nos intervallos perturbação notavel na saúde.

\section{DIAGNOSTICO DIFFERENCIAL.}

A dôr precordial, lancinante, constrictiva, pungitiva, não augmentando pela pressão; a angustia e sensação puramente subjectiva de suffocação; a irradiação da dôr para o pescoço e para o braço e antebraço esquerdos; a marcha paroxystica dos accidentes; a saúde perfeita no intervallo dos accessos, eis as bases em que solidamente se firma diagnostico differencial da angina do peito; são outros tantos testemunhos eloquentes da natureza da molestia, e que não permittem a confusão della com outros padecimentos, mesmo exclusivamente nervosos, do coração." 